\title{
The unknown planktonic foraminiferal pioneer Henry A. Buckley and his collection at The Natural History Museum, London
}

\author{
Marina C. Rillo ${ }^{1,2}$, John Whittaker ${ }^{1}$, Thomas H. G. Ezard ${ }^{2,3}$, Andy Purvis ${ }^{4,5}$, \\ Andrew S. Henderson ${ }^{1,6}$, Stephen Stukins ${ }^{1}$ \& C. Giles Miller ${ }^{*}$ \\ ${ }^{1}$ Department of Earth Sciences, The Natural History Museum, Cromwell Road, London SW7 5BD, UK \\ ${ }^{2}$ Ocean and Earth Science, University of Southampton, National Oceanography Centre, European Way, Southampton SO14 \\ $3 \mathrm{ZH}, \mathrm{UK}$ \\ ${ }^{3}$ Centre for Biological Sciences, University of Southampton, Life Sciences Building 85, Highfield Campus, Southampton \\ SO17 1BJ, UK \\ ${ }^{4}$ Department of Life Sciences, The Natural History Museum, Cromwell Road, London SW7 5BD, UK \\ ${ }^{5}$ Department of Life Sciences, Imperial College London, Silwood Park Campus, Ascot SL5 7PY, UK \\ ${ }^{6}$ Biostratigraphy Group, GLTSD, Saudi Aramco, Dhahran, 31311 Saudi Arabia \\ *Correspondence: G.Miller@nhm.ac.uk
}

\begin{abstract}
The Henry Buckley Collection of Planktonic Foraminifera at the Natural History Museum in London (NHMUK) consists of 1665 single-taxon slides housing 23897 individuals from 203 sites in all the major ocean basins, as well as a vast research library of Scanning Electron Microscope (SEM) photomicrographs. Buckley picked the material from the NHMUK Ocean-Bottom Deposit Collection and also from fresh tow samples. However, his collection remains largely unused as he was discouraged by his managers in the Mineralogy Department from working on or publicizing the collection. Nevertheless, Buckley published pioneering papers on isotopic interpretation of oceanographic and climatic change and was one of the first workers to investigate foraminiferal wall structure using the SEM technique. Details of the collection and images of each slide are available via the NHMUK Data Portal (http://dx.doi.org/10.5519/0035055). The Buckley Collection and its associated Ocean-Bottom Deposit Collection have great potential for taxon-specific studies as well as geochemical work, and both collections are available on request.
\end{abstract}

Keywords: natural history collections; digitization; open-access; zooplankton; sea-bottom

Received 2 June 2016; accepted 6 September 2016

Natural history collections provide a rich source of palaeontological data and contribute to a wide range of biostratigraphic studies at taxonomic, population and community levels. Conserved in museums and other institutions, these repositories contain specimens as primary data curated with associated metadata. One such repository is the Henry Buckley Collection of Planktonic Foraminifera held by the Natural History Museum in London (NHMUK). For convenience in this paper, the abbreviation 'NHMUK' is used throughout, even where the original name of the institution was The British Museum (Natural History). Here we present an overview of the Henry Buckley Collection with the aim of promoting the work of Buckley to the micropalaeontological community and to advocate the use of abundant resources like these held in natural history museums.

\section{Historical background}

The establishment of the Oceanographic Section in the Department of Mineralogy of the NHMUK began with the acquisition, in 1935, of the John Murray Collection. Sir John Murray was one of the naturalists on the voyage of the HMS Challenger and his collection included many of the zoological, botanical and geological specimens collected during the expedition (Lingwood 1981). The Marine Deposits of the Murray Collection consist of 9746 marine samples and formed the nucleus of the NHMUK Ocean-Bottom Deposit (OBD) Collection. The His Egyptian Majesty's Ship Mabahiss John Murray Expedition in 1933-34 further enlarged the OBD Collection with samples from the western Indian Ocean, a region that the HMS Challenger expedition had not visited. Moreover, the Admiralty (British Royal Navy) continuously supplied the OBD Collection with material collected by its survey ships (Kempe \& Buckley 1987). Today the OBD Collection consists of samples from some 40000 geographical locations from all of the world's oceans.

The first Keeper of the OBD Collection was Dr John Dugdale Holt Wiseman (1907-91), who worked at the NHMUK until his retirement in 1972 and was Henry A. Buckley's first manager. Henry Alexander Buckley (1939-2002) joined the NHMUK Oceanographic Section in 1961 to curate the OBD Collection. Buckley had a degree in Geology and Zoology from the University of Manchester. He became interested in foraminiferal research through the encouragement of Dr Wiseman (Kempe \& Buckley 1987). During his working years with the OBD Collection, Buckley amassed a large specimen slide collection of planktonic foraminifera and a research library of SEM photomicrographs for each species that he could recognize morphologically (Fig. 1). His initial work focused on the use of planktonic foraminifera for isotopic interpretation of oceanographic and climatic change (Shackleton et al. 1973). In 1966 Buckley became one of the first scientists to use the SEM technique, when the first SEM (Cambridge Stereoscan Mk II) was purchased by the NHMUK. He used the SEM to examine the wall structure, texture and composition of planktonic foraminifera tests, and appreciated the importance of these characteristics for the group's systematics.

Buckley's passion was to produce an Atlas of Modern Planktonic Foraminifera. He progressed by refining and augmenting his slide collection of specimens from different deep-sea locations and also 


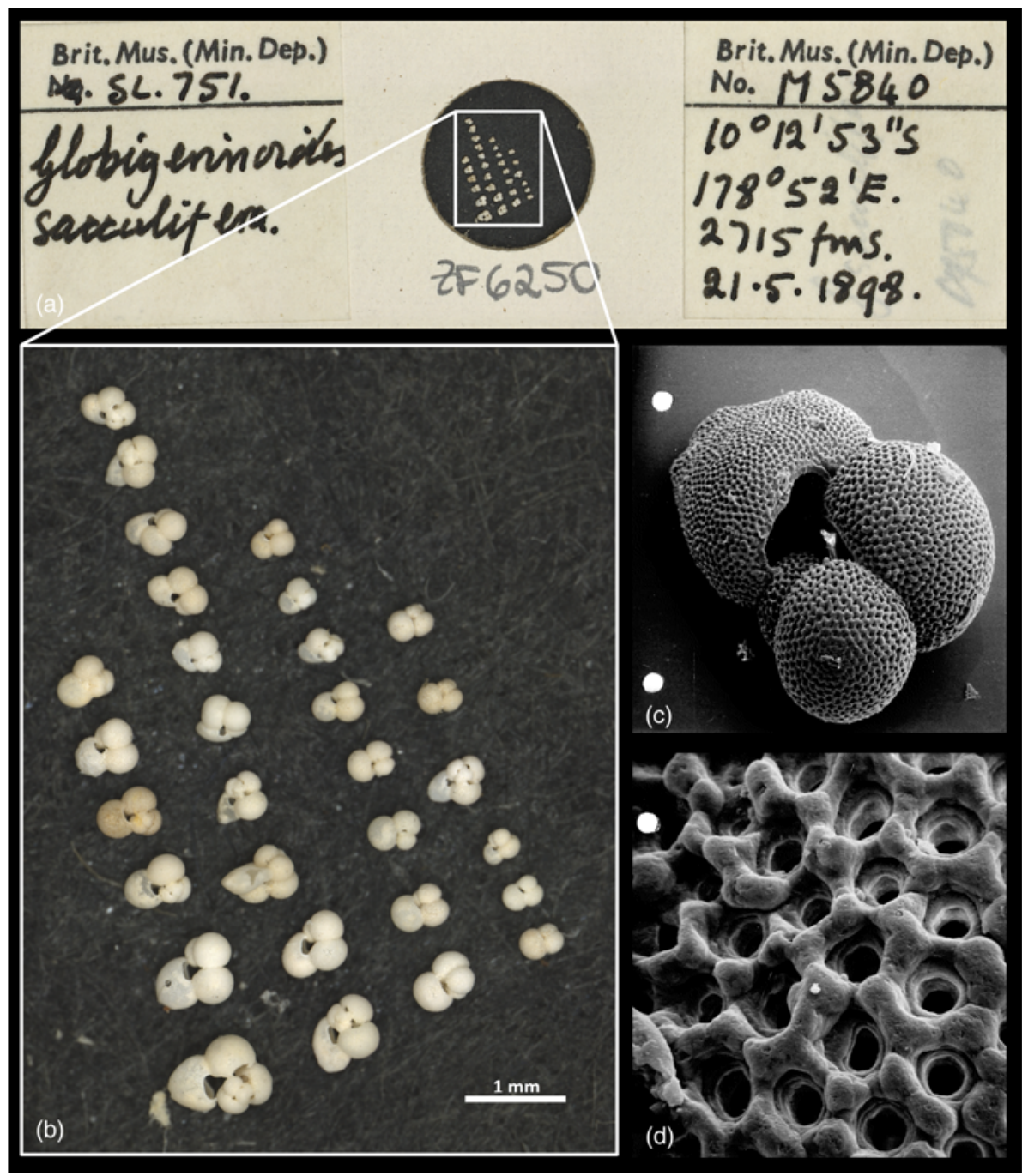

Fig. 1. Example of the contents of the Henry Buckley Collection, NHMUK: (a) slide no. ZF6250 with Trilobatus sacculifer; (b) specimens of the slide no. ZF6250; SEM photomicrographs taken in 1968 of (c) T. sacculifer $\times 130$ magnification; and (d) its wall structure $\times 1300$ magnification. fresh tow samples (from 1953 to 1967). Buckley described a new species (Globorotalia oveyi Buckley, 1973) and used the collection in a series of papers on climate change, glaciation and sapropel formation (Buckley 1976; Buckley et al. 1982; Buckley \& Johnson 1988). Buckley also published on the formation of minerals, such as glauconite (Buckley et al. 1978, 1984; Fleet et al. 1980; Hall \& Buckley 1991), and the mineralogical composition of sediments (Buckley et al. 1974; Easton \& Buckley 1979, 1983; Buckley \& Woolley 1990). Despite early encouragement from Dr Wiseman, Buckley was officially discouraged by his later managers at the NHMUK from working on the biology and taxonomy of planktonic foraminifera for a number of political reasons, and because he was not considered to be a trained micropalaeontologist (Whittaker, pers. comm. 2015). He was never allowed to proceed with his Atlas.

Table 1. Overview of the slide contents of the Henry Buckley Collection, NHMUK

\begin{tabular}{lcc}
\hline Content of slides & $\begin{array}{c}\text { No. of } \\
\text { slides }\end{array}$ & $\begin{array}{c}\text { No. of } \\
\text { specimens }\end{array}$ \\
\hline $\begin{array}{l}\text { Modern macroperforate planktonic } \\
\text { foraminifera }\end{array}$ & 1253 & 15355 \\
$\begin{array}{l}\text { Modern microperforate planktonic } \\
\text { foraminifera }\end{array}$ & 102 & 988 \\
$\begin{array}{l}\text { Fossil planktonic foraminifera } \\
\text { Unidentified foraminifera }\end{array}$ & 87 & 915 \\
Total & 223 & 6639 \\
\hline
\end{tabular}

As a consequence, Buckley is almost unknown within the planktonic foraminiferal community.

\section{The Henry Buckley Collection of planktonic foraminifera}

\section{Slide collection}

The Buckley Collection includes 1665 slides from 203 geographical sites and contains 23897 picked and mounted specimens (Table 1). Each slide is arranged taxonomically and labelled with geographical coordinates and sampling details (Fig. 1a). Of the 203 sites, 79 are represented by plankton tow specimens, 122 from ocean-bottom sediment and two from onshore (Fig. 2). The collection includes core top material and also material from various depths within cores. Topotypes from the original type locality include the species Beella digitata (Brady, 1879), Turborotalita quinqueloba (Natland, 1938), Globorotaloides hexagonus (Natland, 1938) and Neogloboquadrina dutertrei (d'Orbigny, 1839).

Of the 1665 slides, 1355 contain modern planktonic foraminifera (Table 1) sampled from 181 geographical localities world-wide. In total there are 16343 modern specimens: 15355 macroperforate and 988 microperforate (Table 2). Buckley mainly used the taxonomy of Parker (1962) and was able to identify 33 morphospecies in the collection, which are well spread throughout the phylogeny of planktonic foraminifera and cover all recognized ecogroups (Aze et al. 2011).

Only 87 slides (5\%) contain identified extinct planktonic foraminifera (Table 1), corresponding to 21 fossil species and a total of 915 individuals (Table 1). These specimens were sampled 


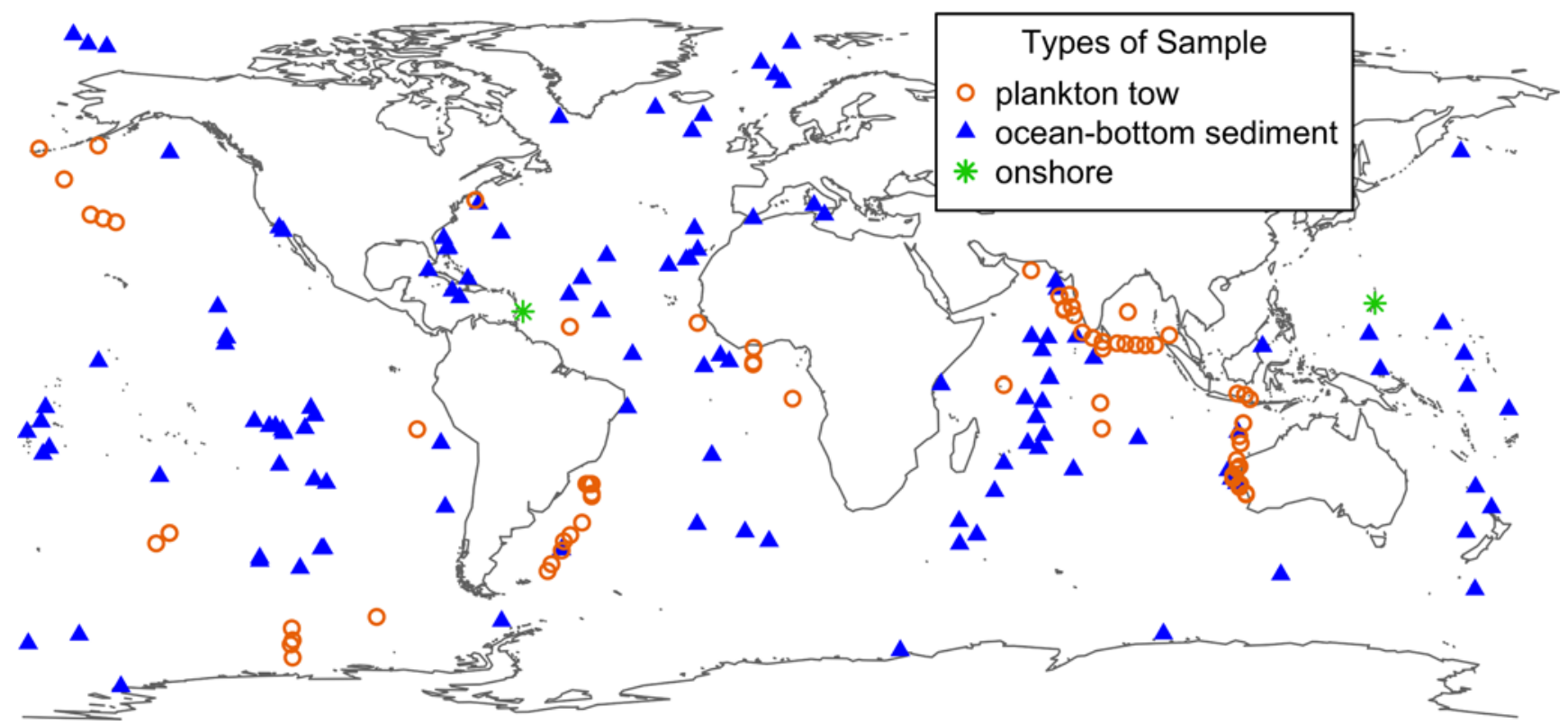

Fig. 2. Map with the sample locations of the Henry Buckley Collection, NHMUK, plotted on modern coordinates.

Table 2. Modern specimens of the Henry Buckley Collection, NHMUK

\begin{tabular}{|c|c|c|c|}
\hline Species name (original) (Henry Buckley) & Species name (revised) (Aze et al. 2011; Spezzaferri et al. 2015) & Number of specimens & Number of sites \\
\hline \multicolumn{4}{|l|}{ Macroperforate } \\
\hline Globorotalia menardii & Menardella menardii & 1753 & 75 \\
\hline Globigerina pachyderma & Neogloboquadrina pachyderma & 1752 & 52 \\
\hline Globigerinoides sacculifera & Trilobatus sacculifer & 1564 & 79 \\
\hline Globigerinoides ruber & Globigerinoides ruber & 1484 & 81 \\
\hline Globoquadrina eggeri/Globigerina dutertrei & Neogloboquadrina dutertrei & 1054 & 76 \\
\hline Globorotalia inflata & Globoconella inflata & 866 & 36 \\
\hline Globorotalia truncatulinoides & Truncorotalia truncatulinoides & 861 & 51 \\
\hline Globigerinella aequilateralis/siphonifera & Globigerinella siphonifera & 855 & 75 \\
\hline Globigerinoides conglobatus & Globigerinoides conglobatus & 774 & 60 \\
\hline Globigerina bulloides & Globigerina bulloides & 675 & 31 \\
\hline Pulleniatina obliquiloculata & Pulleniatina obliquiloculata & 619 & 67 \\
\hline Sphaeroidinella dehiscens & Sphaeroidinella dehiscens & 476 & 41 \\
\hline Globorotalia crassaformis & Truncorotalia crassaformis & 311 & 27 \\
\hline Globigerinoides tenellus & Globoturborotalita tenella & 308 & 26 \\
\hline Globorotalia tumida & Globorotalia tumida & 306 & 31 \\
\hline Globoquadrina conglomerata & Globoquadrina conglomerata & 214 & 28 \\
\hline Globigerina rubescens & Globoturborotalita rubescens & 200 & 23 \\
\hline Globorotalia hirsuta & Hirsutella hirsuta & 179 & 14 \\
\hline Globorotalia scitula & Hirsutella scitula & 166 & 25 \\
\hline Orbulina universa & Orbulina universa & 162 & 24 \\
\hline Globigerinita humilis & Turborotalita humilis & 147 & 14 \\
\hline Globoquadrina hexagona & Globorotaloides hexagonus & 142 & 26 \\
\hline Globigerina calida & Globigerinella calida & 133 & 25 \\
\hline Globigerina falconensis & Globigerina, falconensis & 127 & 13 \\
\hline Globigerina digitata & Beella digitata & 90 & 25 \\
\hline Globigerina quinqueloba & Turborotalita quinqueloba & 77 & 9 \\
\hline Globigerinoides trilobus & Trilobatus trilobus & 47 & 1 \\
\hline Globigerinella adamsi & Globigerinella adamsi & 13 & 8 \\
\hline \multicolumn{4}{|l|}{ Microperforate } \\
\hline Globigerinita glutinata & Globigerinita glutinata & 695 & 43 \\
\hline Candeina nitida & Candeina nitida & 221 & 25 \\
\hline Hastigerina pelagica & Hastigerina pelagica & 34 & 12 \\
\hline Globigerinita iota & Tenuitella iota & 31 & 5 \\
\hline Globigerinita uvula & Globigerinita uvula & 7 & 2 \\
\hline Total & & 16343 & 181 \\
\hline
\end{tabular}

The table shows the species' name (original and revised), ordered by the number of mounted specimens in the slide collection, and the number of geographical sites from which these specimens came. 
from 27 different geographical localities, mostly concentrated within tropical latitudes of the Atlantic, Pacific and Indian oceans plus the Mediterranean Sea. There are also samples from onshore sites: Bissex Hill nappe on Barbados (Caribbean) and the Saipan Island Limestone (Pacific Ocean) (Fig. 2). Several locations contain fossil material derived from multiple depths. The deepest sample was taken from 950 to $953 \mathrm{~cm}$ below the seafloor in the Western Central Atlantic Ocean by RV Vema in 1959.

\section{Scanning electron microscope photomicrographs}

The Buckley Collection includes 100 files of SEM photomicrographs, arranged by planktonic foraminiferal taxon, plus 23 files of nannofossil images. These files are curated with museum numbers, which allow the access to geographical and cruise information. In total, there are more than 1000 photomicrographs (Fig. 1c and d).

\section{Digitization of the Buckley slide collection}

In 2015 the collection was entered into a database using information from the slides and derived information from the OBD Collection, such as core length or total sediment mass sampled. Water depth measurements available with the collection were mostly reported in fathoms. We added more precise and repeatable water depth values based on modern bathymetric models using the $R$ marmap package (Pante \& Simon-Bouhet 2013; R Core Team 2013) with five arcminute resolution. Slides were imaged in the NHMUK Sackler Biodiversity Imaging Laboratory using a Zeiss Axio Zoom V16 microscope and the ZEN software. Images were taken of whole slides and labels at $3.5 \times$ magnification $(18.43 \times 18.43 \mu \mathrm{m}$ per pixel, Fig. 1a) and added to the NHMUK data portal. More detailed images of the specimens on each slide were also taken at $25 \times$ magnification $(2.58 \times 2.58 \mu \mathrm{m}$ per pixel, Fig. $1 \mathrm{~b})$.

\section{Future use of the collection}

The Henry Buckley Collection of Planktonic Foraminifera is available for study as part of the NHMUK Micropalaeontology Collection at South Kensington, London. The OBD Collection, including the original samples studied by Buckley, is located at the NHMUK off-site storage facility and also available on request. Information about each slide of the Buckley Collection can be found on the NHMUK Data Portal (http://data.nhm.ac.uk). Searching for a particular planktonic foraminiferal taxon is most efficient. To help with locating relevant specimen data, a file of the whole dataset has been deposited on the portal (http://doi.org/10.5519/0035055).

Our ongoing work seeks to understand and quantify possible biases in the Henry Buckley Collection. Sediments from the OBD Collection used by Buckley have been resampled and reprocessed to assess taxonomic bias (systematic misidentification or incomplete representation of the assemblage) and size bias (bias towards picking out larger specimens or larger species). Once this bias analysis is complete, it will be added along with morphometric data to the collection dataset on the NHMUK Data Portal. Both will be discussed fully in future publications.

The Buckley Collection and the OBD Collection include historical sampling events dating back from the 1870s. Destructive sampling is possible for geochemical analyses, which allow the study of the consequences of human impact on the oceans in the intervening period, e.g. ocean acidification (Moy et al. 2009). The global scope of the Buckley Collection and the abundance of modern specimens favour taxon-specific macroecological studies, such as the investigation of what drives the biogeography and size distribution of modern planktonic foraminifera species.

\section{Acknowledgements and Funding}

The authors would like to thank Rebecca Summerfield, Vladimir Blagoderov and Alex Ball for their assistance at the NHMUK during the imaging of the Buckley Collection. MCR is funded by GSNOCS. THGE is funded by NERC Fellowship NE/J018163/1. Purchase of the equipment used to image the slides was funded by the NERC Strategic Environmental Capital Call.

Scientific editing by Alan Lord

\section{References}

Aze, T., Ezard, T.H., Purvis, A., Coxall, H.K., Stewart, D.R., Wade, B.S. \& Pearson, P.N. 2011. A phylogeny of Cenozoic macroperforate planktonic foraminifera from fossil data. Biological Reviews, 86, 900-927.

Buckley, H.A. 1973. Globorotalia (Clavatorella) oveyi n. sp., première mention Récente d'un sous-genre de foraminifère du Néogenè. Revue de Micropaléontologie, 16, 168-172.

Buckley, H.A. 1976. The Discovery Tablemount chain. Deep Sea Research and Oceanographic Abstracts, 23, 937-948.

Buckley, H.A. \& Johnson, L.R. 1988. Late Pleistocene to Recent sediment deposition in the central and western Mediterranean. Deep Sea Research Part A. Oceanographic Research Papers, 35, 749-766.

Buckley, H.A. \& Woolley, A.R. 1990. Carbonates of the magnesite-siderite series from four carbonatite complexes. Mineralogical Magazine, 54 413-418.

Buckley, H.A., Easton, A.J. \& Johnson, L.R. 1974. Iron and manganese encrustations in Recent sediments. Nature, 249, 436-437.

Buckley, H.A., Bevan, J.C., Brown, K.M. \& Johnson, L.R. 1978. Glauconite and celadonite: two separate mineral species. Mineralogical Magazine, 42 373-382.

Buckley, H.A., Johnson, L.R., Shackleton, N.J. \& Blow, R.A. 1982. Late glacial to Recent cores from the eastern Mediterranean. Deep Sea Research Part A. Oceanographic Research Papers, 29, 739-766.

Buckley, H.A., Easton, A.J. \& Johnson, L.R. 1984. Compositional variations in glauconite. Mineralogical Magazine, 48, 119-126.

Easton, A.J. \& Buckley, H.A. 1979. Iron meteorites of Group IA and IIA-Study of phosphide morphology enhanced by dry $\mathrm{Cl} 2$ etching. Meteoritics, 14, $143-152$.

Easton, A.J. \& Buckley, H.A. 1983. Plessite textures in the Toluca (Group IA) iron meteorite revealed by the selective attack of chlorine. Mineralogical Magazine, 47, 413-415.

Fleet, A.J., Buckley, H.A. \& Johnson, L.R. 1980. The rare earth element geochemistry of glauconites and celadonites. Journal of the Geological Society, London, 137, 683-688, http://doi.org/10.1144/gsjgs.137.6.0683

Hall, A. \& Buckley, H.A. 1991. Ammonium in glauconite and celadonite Mineralogical Magazine, 55, 280-282.

Kempe, D.R.C. \& Buckley, H.A. 1987. Fifty years of oceanography in the Department of Mineralogy, British Museum (Natural History). Bulletin of the British Museum (Natural History), Historical, 15, 59-97.

Lingwood, P.F. 1981. The dispersal of the collections of H.M.S. Challenger; an example of the importance of historical research in tracing a systematically important collection. Archives of Natural History, 1, 71-77.

Moy, A.D., Howard, W.R., Bray, S.G. \& Trull, T.W. 2009. Reduced calcification in modern Southern Ocean planktonic foraminifera. Nature Geoscience, 2, 276-280.

Pante, E. \& Simon-Bouhet, B. 2013. marmap: A package for importing, plotting and analyzing bathymetric and topographic data in R. PLoS One, 8, p.e73051.

Parker, F.L. 1962. Planktonic foraminiferal species in Pacific sediments Micropaleontology, 8, 219-254

R Core Team 2013. R: A language and environment for statistical computing, http://www.r-project.org

Shackleton, N.J., Wiseman, J.D.H. \& Buckley, H.A. 1973. Non-equilibrium isotopic fractionation between seawater and planktonic foraminiferal tests. Nature, 242, 177-179.

Spezzaferri, S., Kucera, M. et al. 2015. Fossil and genetic evidence for the polyphyletic nature of the planktonic foraminifera 'Globigerinoides', and description of the new genus Trilobatus. PLoS One, 10, p.e0128108, http:/ doi.org/10.1371/journal.pone.0128108 